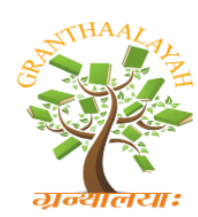

\author{
INTERNATIONAL JOURNAL OF RESEARCH - \\ GRANTHAALAYAH \\ A knowledge Repository
}

Science

\title{
GAS CHROMATOGRAPHY - MASS SPECTROMETRY (GC-MS) IN ORGANIC GEOCHEMICAL INVESTIGATION OF CRUDE OILS FROM KIKINDA AND VELEBIT FIELDS IN SERBIA
}

\author{
Hamza Khalifa ${ }^{* 1}$, Abdussalam Ali Ahmed², Ayiman Abusaediyah ${ }^{3}$, Aejeeliyah Yousuf ${ }^{4}$, \\ Salheen Grimida ${ }^{5}$ \\ $1,4,5$ Higher Institute of Medical Sciences, Bani Walid, Libya \\ ${ }^{2}$ Mechanical Engineering Department, Bani Waleed University/ Libya \\ ${ }^{3}$ Chimestry Department, Faculty of Science, Bani Waleed University/ Libya
}

DOI: https://doi.org/10.29121/granthaalayah.v5.i6.2017.2073

\begin{abstract}
In this work two crude oil samples were investigated to present the difference between biodegraded (Velebit) and non-degraded (Kikinda) oil. Two samples are from the Velebit oil-gas field and the Kikinda oil-gas field. These are two of the largest oil and gas deposits in the Serbian part of the Pannonian Basin. In the experimental part of this work, two samples of crude oil were separated by column chromatography. Saturated hydrocarbons were analyzed by gas chromatography-mass spectrometry instruments. Based on the abundance and distribution of biomarkers, it could be conclude that the distribution is typical of oil in both samples, with difference in the distribution of n-alkane. GC-MS chromatogram of n-alkanes and isoprenoids of saturated fraction isolated from Velebit crude oil show the distribution typical of oils altered by biodegradation.
\end{abstract}

Keywords: Gas Chromatography (GC); Mass Spectrometry (MS); N-Alkanes Biodegradation; Biodegradation.

Cite This Article: Hamza Khalifa, Abdussalam Ali Ahmed, Ayiman Abusaediyah, Aejeeliyah Yousuf, and Salheen Grimida. (2017). "GAS CHROMATOGRAPHY - MASS SPECTROMETRY (GC-MS) IN ORGANIC GEOCHEMICAL INVESTIGATION OF CRUDE OILS FROM KIKINDA AND VELEBIT FIELDS IN SERBIA." International Journal of Research - Granthaalayah, 5(6), 550-560. 10.29121/granthaalayah.v5.i6.2017.2073.

\section{Introduction}

Crude oil and its derivatives, as the key energy-generating substances and raw materials used for production, are very widely used in all domains of work and everyday life. With the advent of oil as a fuel, there was the most intense economic growth and it can be said that the entire modern civilization is based on the utilization of oil. 
However, rapid growth and development of civilization in the past two centuries with the mass use of fossil fuels has led to imbalances and distortions of natural processes. In spite of improvements in technology and equipment used for oil drilling, transport and processing by the petroleum industry, oil and oil derivatives represent a significant source of environmental contamination. (Beškoski V., Gojgić-Cvijović G., Jovančićević B., Vrvić M., in Gas Chromatography - Biochemicals, Narcotics and Essential Oils, B. Salih, Ö. Çelikbıçak, Eds., InTech, Rijeka, Croatia, 2012).

Petroleum and petroleum products are complex mixtures consisting of thousands of compounds that are usually grouped into four fractions: aliphatics, aromatics, nitrogen- oxygen-sulphur (NSO) compounds and asphaltenes. Asphaltenes are generally solvent insoluble and resistant to biodegradation. Aliphatic hydrocarbons consist of normal alkanes (n-alkanes), branched alkanes (isoalkanes) and cyclic alkanes (naphthenes). Isoalkanes, naphthenes and aromatics are much less biodegradable than n-alkanes. The fraction of saturated hydrocarbons is the dominant fraction in most oils as compared to aromatic hydrocarbons and NSO compounds.

When crude oil or petroleum products are accidentally released into the environment, they are immediately subject to a wide variety of weathering process. These weathering processes can include: evaporation, dissolution, microbial degradation, dispersion and water-oil emulsification, photooxidation, adsorption onto suspended. Biomarkers are complex organic compounds composed of carbon, hydrogen and other elements such as oxygen, nitrogen and sulfur. Biomarker compounds are analyzed using gas chromatography and mass spectrometry and they are divided into several basic types of n-alkanes and isoprenoid n-alkane, steranes, diterpanes, triterpanes and their derivatives and aromatic hydrocarbons. (Dougle W. Waples, 1945Geochemistry in petroleum exploration).

In this work two crude oil samples were investigated to present the difference between biodegraded (Velebit) and non-degraded (Kikinda) oil. In the experimental part of this work, two samples of crude oil were separated by column chromatography. Saturated hydrocarbons were collected in the first fraction and eluted by petroleum ether and then, aromatic hydrocarbons with some sulfur were collected in the second fraction and eluted by mixture solvent petroleum ether and benzene (2:1, v:v). Saturated hydrocarbons were analyzed by gas chromatography -mass spectrometry instruments. (Niessen W.M.A. (2001) Current practise of Gas chromatographyMass spectrometry; Copyright by Marcel Dekker, Inc).

\section{Materials and Methods}

The study aims to analyze the effect of two of the crude oil samples were investigated in this thesis originated from the Velebit oil-gas field and the Kikinda oil-gas field. These are two of the largest oil and gas deposits in the Serbian part of the Pannonian Basin.

The analysis of these two eyes through your device Gas chromatography - Mass spectrometry (GC-MS). 


\section{Results and Discussions}

The crude oils (a sample form the Velebit oil-gas field and a sample from Kikinda oil-gas field) were separated into saturated and aromatic using column chromatography over silica gel. Saturated hydrocarbon fraction was eluted with petroleum ether, aromatic hydrocarbons with mixture of petroleum ether and benzene (2:1, v:v) and the NSO fractions (polar fraction) was determined from the difference to $100 \%$.

Table 1: Mass of sample, adsorbent and solvent.

\begin{tabular}{|l|l|l|l|l|}
\hline \multicolumn{1}{|c|}{ Sample } & \multicolumn{1}{|c|}{$\begin{array}{c}\text { Mass of } \\
\text { sample } \mathbf{( m g )}\end{array}$} & $\begin{array}{c}\text { Mass of } \\
\mathbf{S i O}_{\mathbf{2}}(\mathbf{g})\end{array}$ & $\begin{array}{c}\text { V petroleum } \\
\text { ether }(\mathbf{m l})\end{array}$ & $\begin{array}{c}\text { V petroleum ether/ } \\
\text { Benzene }(\mathbf{m l})\end{array}$ \\
\hline Kikinda crude oil & 30.20 & 9.06 & 67.95 & 113.25 \\
\hline Velebitn Crude oil & 34.80 & 10.44 & 78.30 & 130.50 \\
\hline
\end{tabular}

In column chromatography, a glass tube $50 \mathrm{~cm}$ in length was held a vertical position and filled with silica gel suspended in solvent (n-hexane) after the addition of a small amount of cotton in the bottom of the column. The amount of $30 \mathrm{mg}$ of crude oil was added to the top of the column (Figure 1). The hydrocarbon solvent (petroleum ether) dissolved the saturated hydrocarbons and carried them slowly along with it down the column. The other more polar compounds of the bitumen remain stationary or move much more slowly than the saturated, which rates of movement depend on the relative affinity of bitumen molecules for the solvent and for the stationary phase (silica gel). Non polar molecules move rapidly because they have little affinity for the highly polar stationary phase.

In contrast, other molecules including aromatic hydrocarbons and polar NSO compounds are held much more by stationary phase and can not be eluted from the column by petroleum ether. Petroleum ether was allowed to pass through the column until the saturated hydrocarbons were eluted and collected in the first fraction. Aromatic hydrocarbons with some sulfur were collected in the second fraction and eluted by mixture solvent petroleum ether and benzene $(2: 1, \mathrm{v}: \mathrm{v})$ respectively. After solvents of these fractions (saturated hydrocarbons and aromatic hydrocarbons) were removed also with rotary evaporator and then transferred these fractions into small glass tubes.

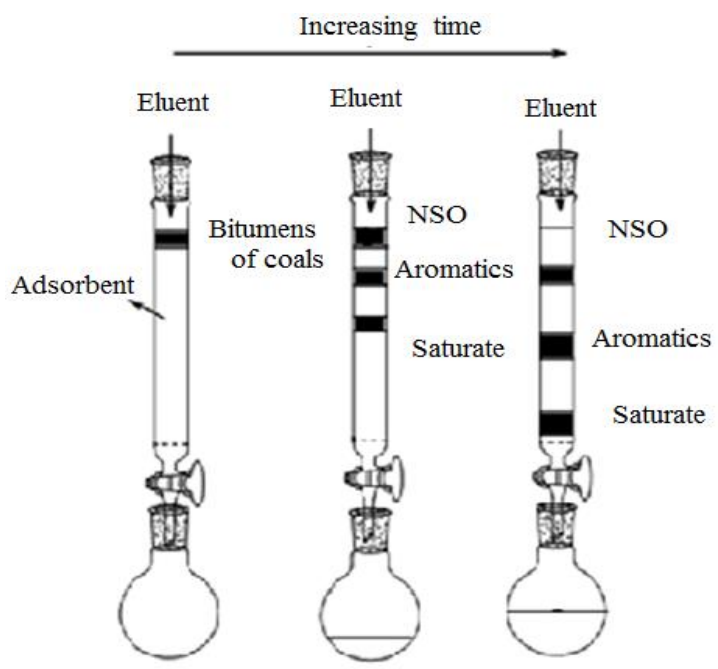

Figure 1: Column-chromatography separation of fractions bitumens of coals. 


\section{Gas Chromatographic - Mass Spectrometric (GC-MS) Analyses}

Saturated hydrocarbons were analyzed by gas chromatography-mass spectrometry (GC-MS). A gas chromatograph Agilent 7890A GC (H5-MS capillary column, $30 \mathrm{~m}$ x $0.25 \mathrm{~mm}$, He carrier gas $1.5 \mathrm{~cm} 3 / \mathrm{min}$, FID) coupled to a Agilent $5975 \mathrm{C}$ mass selective detector $(70 \mathrm{eV})$ was used. The column was heated from 80 to $310{ }^{\circ} \mathrm{C}$, at a rate of $2{ }^{\circ} \mathrm{C} / \mathrm{min}$, and the final temperature of $310^{\circ} \mathrm{C}$ was maintained for an additional $25 \mathrm{~min}$. Detailed analyses of the target compounds were conducted using the following ion chromatograms: $m / z=71$ ( $n$-alkanes and isoprenoids), $m / z=$ 191 (terpanes) and $m / z=217$ (steranes). The individual peaks were identified by comparison with the literature data12 and on the basis of the total mass spectra (library: NIST5a). Biomarker parameters were calculated from GC-MS chromatogram peak areas (software GCMS Data Analysis).

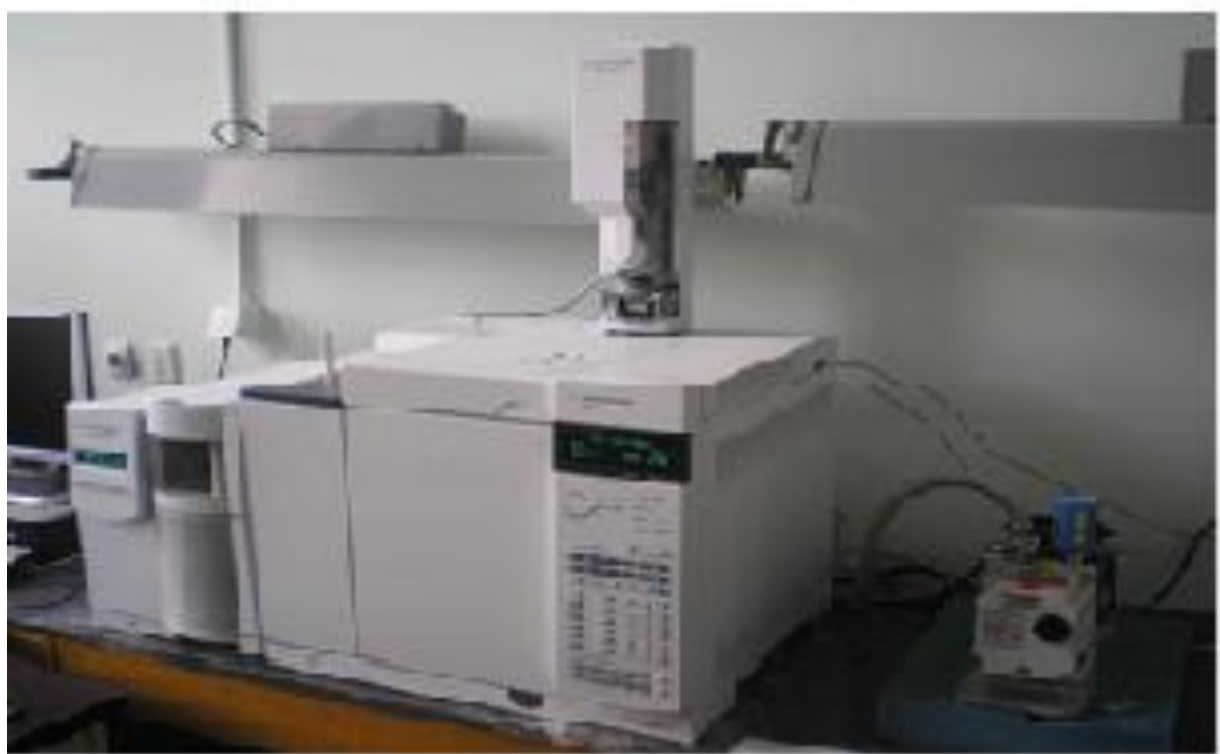

Figure 2: Gas chromatograph Agilent 7890N and a Hewlett-Packard 5972 MSD.

Table 2: Values of group organic geochemical parameters.

\begin{tabular}{|l|l|l|l|}
\hline Sample & Saturated HC $\mathbf{( \% )}$ & Aromatic HC $(\boldsymbol{\%})$ & NSO $(\boldsymbol{\%})$ \\
\hline Kikinda crude oil & 48.01 & 18.87 & 33.12 \\
\hline Velebit crude oil & 47.13 & 29.02 & 23.85 \\
\hline
\end{tabular}

\section{Specific Organic Geochemical Parameters}

Kikinda crud oil: $\mathrm{n}$-alkanes are identified in range $\mathrm{C} 12$ to $\mathrm{C} 38$ with a maximum at $\mathrm{n}$-C16 (Figure 3 ). The CPI value is 1.2 , close to 1 , which is typical of mature organic matter and an oil distribution. The $\mathrm{Pr} / \mathrm{n}-\mathrm{C} 17$ and Phyt/n-C18 values is $<1$, which can be an indicator of a fair degree of OM maturity. The pristane (Pr) to phytane (Phyt) ratio is widely used as a redox indicator of the depositional environment. Pristane dominates over phytane, which is indicative of organic matter formation in a oxygenous environment. Biomarker parameters (CPI, Pr/Fit ) indicated a mixed origin of the organic matter (Table3). 
Velebit crude oil: n-alkanes are identified in range $\mathrm{C} 12$ to $\mathrm{C} 38$ with a maximum at n-C16 (Figure 3). GC-MS chromatogram $(\mathrm{m} / \mathrm{z} 71)$ of saturated fraction show the distribution typical of oils altered by biodegradation. The n-alkanes are not most abundant, while pristane (Pr) and phytane (Phy) dominate. The $\mathrm{Pr} / \mathrm{n}-\mathrm{C} 17$ and $\mathrm{Ph} / \mathrm{n}-\mathrm{C} 18$ values is $>1$, which is also an indicator of biodegradation .Phytane dominates over pristane, which is indicative of organic matter formation in a reducing environment (Table 3 ).

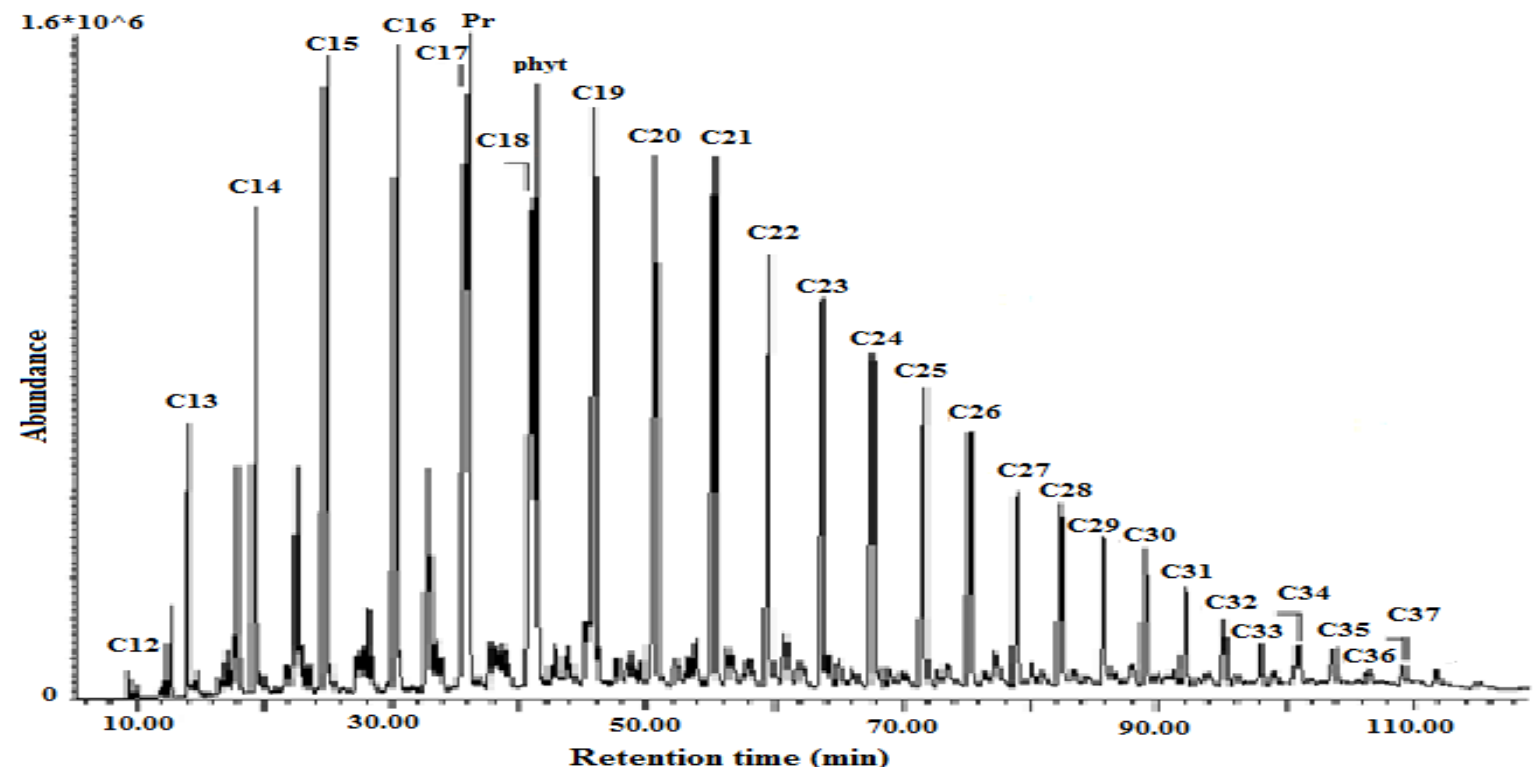

Figure 3: GC-MS chromatogram of n-alkanes and isoprenoids, m/z 71 of saturated fraction isolated from Kikinda crude oil.

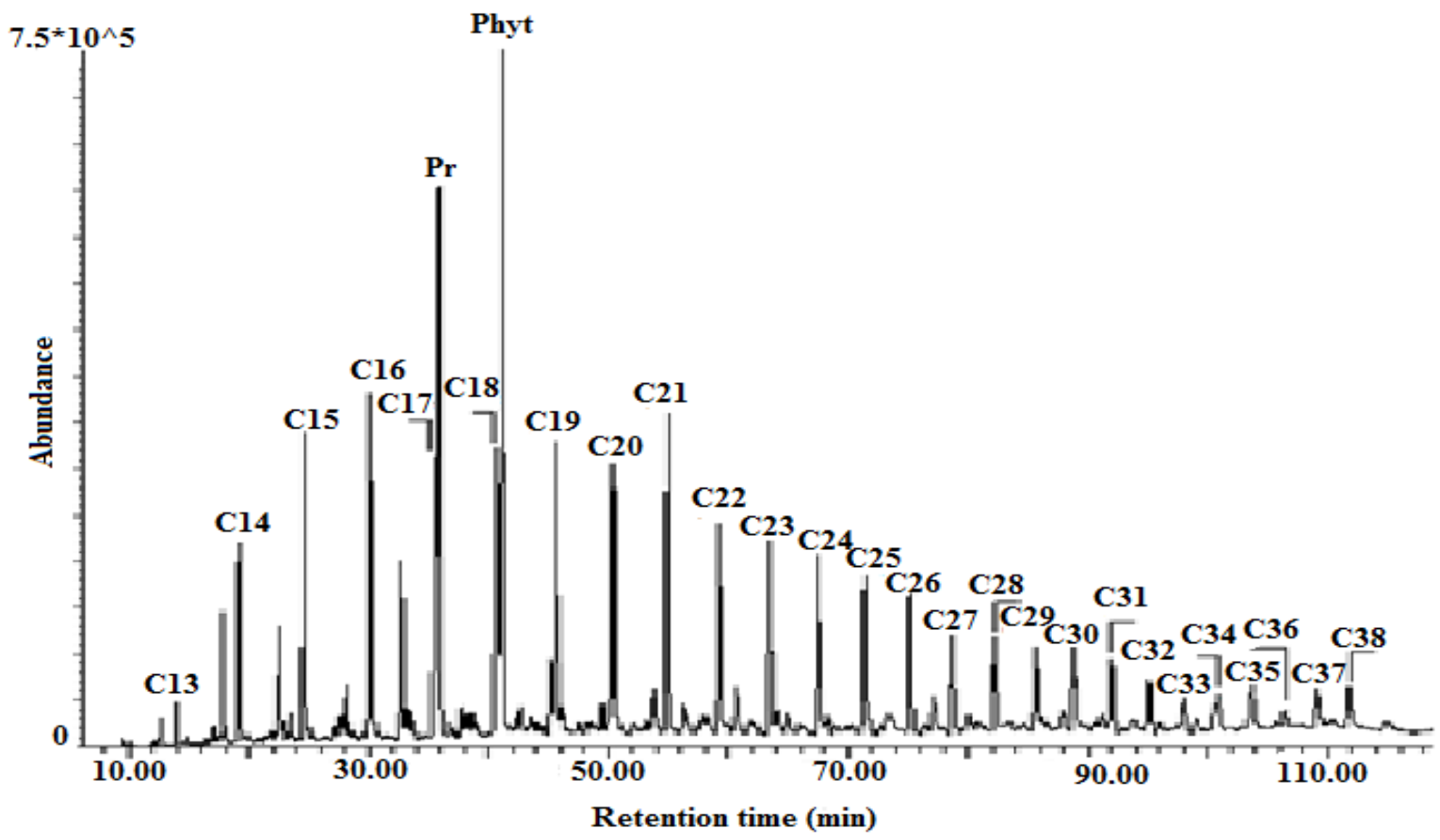

Figure 4: GC-MS chromatogram of n-alkanes and isoprenoids, m/z 71 of saturated fraction isolated from Velebit crude oil. 
Table 3: Values of specific organic geochemical parameters calculated from distributions and abundances of n-alkanes and isoprenoides.

\begin{tabular}{|l|l|l|l|l|l|l|}
\hline Sample & $\boldsymbol{n}$-alkane range & $\boldsymbol{n}$-alkane max. & $\mathbf{C P I}$ & $\mathbf{P r} / \mathbf{P h y t}$ & $\mathbf{P r} / \boldsymbol{n}$ - $\mathbf{C}_{\mathbf{1 7}}$ & $\mathbf{P h y t}_{\boldsymbol{n}} \boldsymbol{n}-\mathbf{C}_{\mathbf{1 8}}$ \\
\hline Kikinda crude oil & $\mathrm{C}_{12}-\mathrm{C}_{38}$ & $\mathrm{C}_{16}$ & 1.2 & 0.98 & 0.75 & 0.74 \\
\hline Velebit crude oil & $\mathrm{C}_{13}-\mathrm{C}_{38}$ & $\mathrm{C}_{16}$ & 1.01 & 0.78 & 1.01 & 1.77 \\
\hline
\end{tabular}

\section{Steranes}

Kikinda crude oil: sterane distributions is typical of oil, with thermodynamically more stable isomers, $5 \alpha(\mathrm{H}) 14 \alpha(\mathrm{H}) 17 \alpha(\mathrm{H}) 20(\mathrm{~S}), 5 \alpha(\mathrm{H}) 14 \beta(\mathrm{H}) 17 \beta(\mathrm{H}) 20(\mathrm{R})$, and $5 \alpha(\mathrm{H}) 14 \beta(\mathrm{H}) 17 \beta(\mathrm{H}) 20(\mathrm{~S})$ configurations, typical geoisomers, and $13 \beta(\mathrm{H}) 17 \alpha(\mathrm{H})$ - and $13 \alpha(\mathrm{H}) 17 \beta(\mathrm{H})$-diasteranes (Figure 24). The use of the $14 \alpha(\mathrm{H}) 17 \alpha(\mathrm{H}) 20(\mathrm{R}) \mathrm{C}_{27}-\mathrm{C}_{29}$ regular steranes in the evaluation of the $\mathrm{OM}$ type is based on the observation that $\mathrm{C}_{27}$ steranes originate dominantly from marine plankton, $\mathrm{C}_{28}$ steranes from yeast, fungi, plankton and algae, and $\mathrm{C}_{29}$ steranes from higher plants and brown and green algae. However, this use has limitations, considering that it is known that marine algae produce sterols with 27 to 29 carbons. Based on percent of $\mathrm{C}_{27}, \mathrm{C}_{28}$ and $\mathrm{C}_{29}$, we concede that Kikinda crude oil has a mixed origin of the organic matter, dominated by terestrial organic matter. Values of sterane maturity ratios are in the range typical for crude oils (Table 12).

Velebit crude oil: sterane distributions is typical of oil (Figure 25). As mentioned above, the distribution of $14 \mathrm{a}(\mathrm{H}), 17 \mathrm{a}(\mathrm{H}), 20 \mathrm{R} \mathrm{C}_{27}-\mathrm{C}_{29}$ regular steranes is use in the evaluation of organic matter type in the depositional environment. The distribution of $\mathrm{C}_{27}-\mathrm{C}_{29}$ regular steranes in Velebit crude oil indicating a mixed origin for the oils. Values of sterane maturity ratios show that Velebit crude oil is less mature than Kikinda crude oil (Table 12).

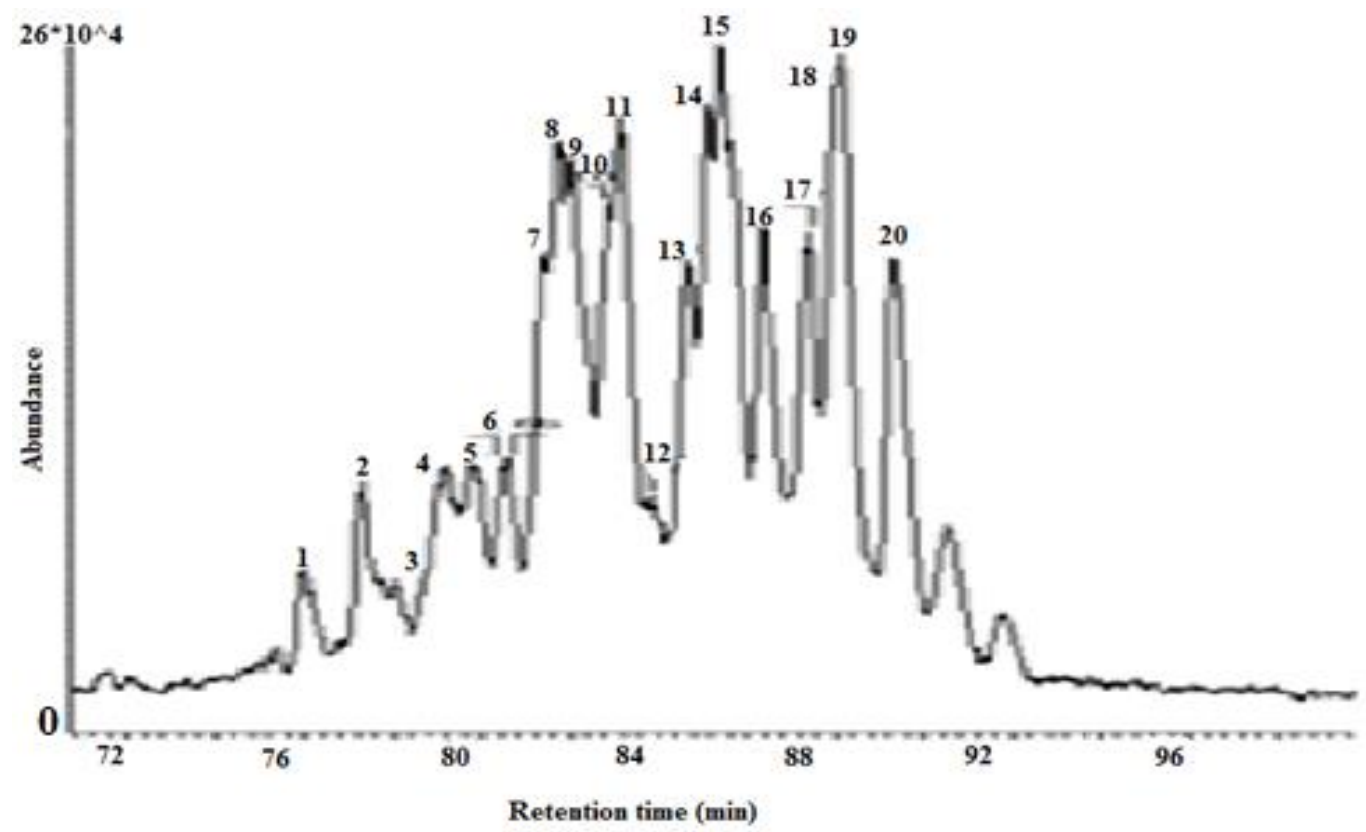

Figure 5: GC-MS chromatogram of steranes $m / z 217$ of saturated fraction isolated from Kikinda crude oil (Peak identification is shown in Table 4). 


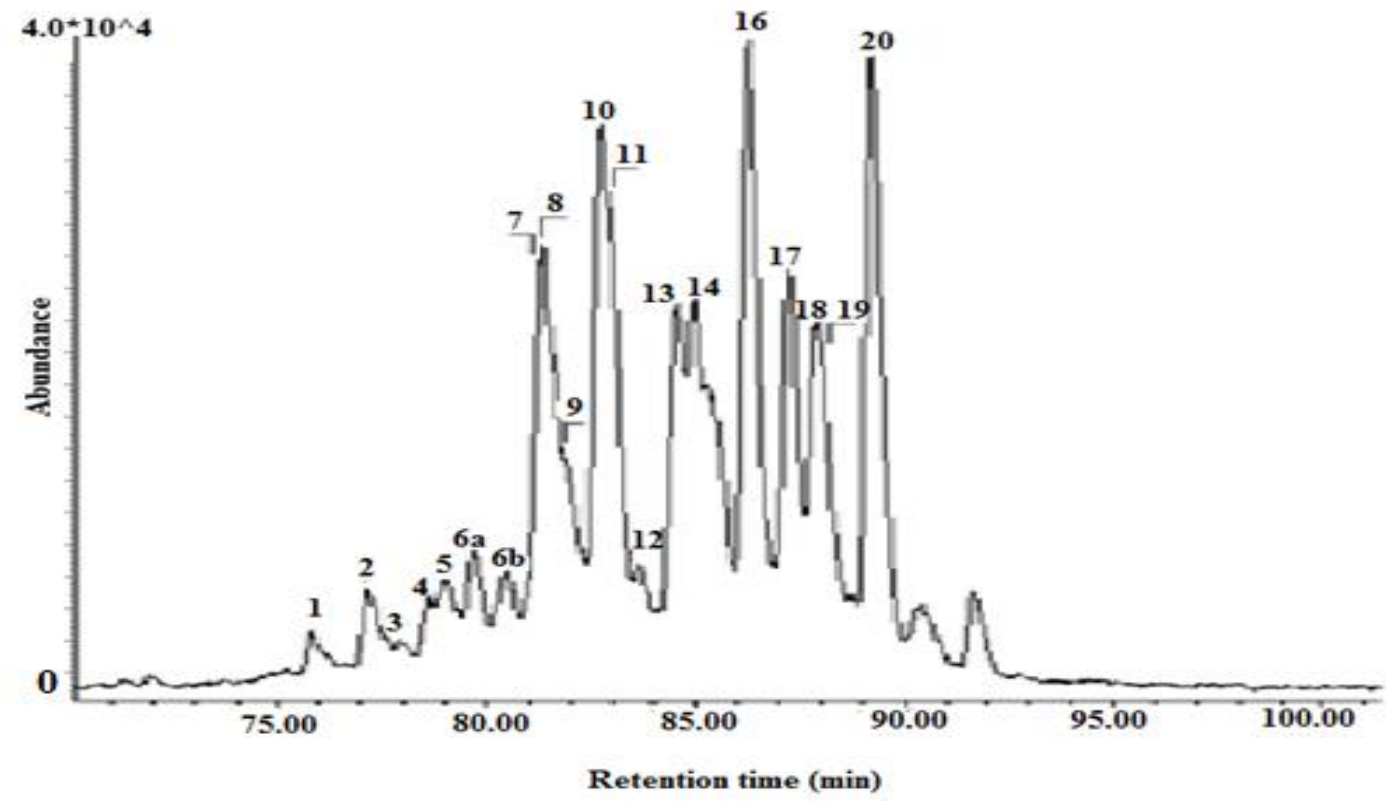

Figure 6: GC-MS chromatogram of steranes, $m / z 217$ of saturated fraction isolated from Velebit crude oil (Peak identification is shown in Table 4).

Table 4: Identification of the peaks in the chromatogram shown in Figures 24 and 6 (steranes).

\begin{tabular}{|c|c|}
\hline Peaks & Compound \\
\hline 1 & $\mathrm{C}_{27} 13 \beta(\mathrm{H}) 17 \alpha(\mathrm{H}) 20(\mathrm{~S})$-diasterane \\
\hline 2 & $\mathrm{C}_{27} 13 \beta(\mathrm{H}) 17 \alpha(\mathrm{H}) 20(\mathrm{R})$-diasterane \\
\hline 3 & $\mathrm{C}_{27} 13 \alpha(\mathrm{H}) 17 \beta(\mathrm{H}) 20(\mathrm{~S})$-diasterane \\
\hline 4 & $\mathrm{C}_{27} 13 \alpha(\mathrm{H}) 17 \beta(\mathrm{H}) 20(\mathrm{R})$-diasterane \\
\hline $5 a$ & $\mathrm{C}_{28} 13 \beta(\mathrm{H}) 17 \alpha(\mathrm{H}) 20(\mathrm{~S}) 24(\mathrm{~S})$-diasterane \\
\hline $5 b$ & $\mathrm{C}_{28} 13 \beta(\mathrm{H}) 17 \alpha(\mathrm{H}) 20(\mathrm{~S}) 24(\mathrm{R})$-diasterane \\
\hline $6 a$ & $\mathrm{C}_{28} 13 \beta(\mathrm{H}) 17 \alpha(\mathrm{H}) 20(\mathrm{R}) 24(\mathrm{~S})$-diasterane \\
\hline $6 b$ & $\mathrm{C}_{28} 13 \beta(\mathrm{H}) 17 \alpha(\mathrm{H}) 20(\mathrm{R}) 24(\mathrm{R})$-diasterane \\
\hline 7 & $\begin{array}{l}\mathrm{C}_{28} 13 \alpha(\mathrm{H}) 17 \beta(\mathrm{H}) 20(\mathrm{~S}) \text {-diasterane } \\
\text { sterane }\end{array}$ \\
\hline 8 & $\begin{array}{l}\mathrm{C}_{29} 13 \beta(\mathrm{H}) 17 \alpha(\mathrm{H}) 20(\mathrm{~S}) \text {-diasterane } \\
\text { sterane }\end{array}$ \\
\hline 9 & $\begin{array}{l}\mathrm{C}_{28} 13 \alpha(\mathrm{H}) 17 \beta(\mathrm{H}) 20(\mathrm{R}) \text {-diasterane } \\
\text { sterane }\end{array}$ \\
\hline 10 & $\mathrm{C}_{27} 14 \alpha(\mathrm{H}) 17 \alpha(\mathrm{H}) 20(\mathrm{R})$-sterane \\
\hline 11 & $\mathrm{C}_{29} 13 \beta(\mathrm{H}) 17 \alpha(\mathrm{H}) 20(\mathrm{R})$-sterane \\
\hline 12 & $\mathrm{C}_{29} 13 \alpha(\mathrm{H}) 17 \beta(\mathrm{H}) 20(\mathrm{~S})$-sterane \\
\hline 13 & $\mathrm{C}_{28} 14 \alpha(\mathrm{H}) 17 \alpha(\mathrm{H}) 20(\mathrm{~S})$-sterane \\
\hline 14 & $\begin{array}{l}\mathrm{C}_{29} 13 \alpha(\mathrm{H}) 17 \beta(\mathrm{H}) 20(\mathrm{R}) \text {-diasterane } \\
\text { sterane }\end{array}$ \\
\hline 15 & $\mathrm{C}_{28} 14 \beta(\mathrm{H}) 17 \beta(\mathrm{H}) 20(\mathrm{~S})$-sterane \\
\hline 16 & $\mathrm{C}_{28} 14 \alpha(\mathrm{H}) 17 \alpha(\mathrm{H}) 20(\mathrm{R})$-sterane \\
\hline 17 & $\mathrm{C}_{29} 14 \alpha(\mathrm{H}) 17 \alpha(\mathrm{H}) 20(\mathrm{~S})$-sterane \\
\hline 18 & $\mathrm{C}_{29} 14 \beta(\mathrm{H}) 17 \beta(\mathrm{H}) 20(\mathrm{R})$-sterane \\
\hline
\end{tabular}


Table 5: Values of specific organic geochemical parameters calculated from distributions and abundances of steranes.

\begin{tabular}{|l|l|l|l|l|l|}
\hline Sample & $\mathbf{C}_{\mathbf{2 9}}$ sterane 20S/(20S+20R) & $\mathbf{C}_{\mathbf{2 9}}$ sterane- $\boldsymbol{\beta} \boldsymbol{\beta} / \boldsymbol{\beta} \boldsymbol{\beta}+\boldsymbol{\alpha \alpha}$ & $\mathbf{C}_{\mathbf{2 7}}(\mathbf{\%})$ & $\mathbf{C}_{\mathbf{2 8}}(\mathbf{\%})$ & $\mathbf{C}_{\mathbf{2 9}} \mathbf{( \% )}$ \\
\hline Kikinda & 0.65 & 0.59 & 29.26 & 30.48 & 40.24 \\
\hline Velebit & 0.47 & 0.50 & 29.29 & 34.39 & 36.30 \\
\hline
\end{tabular}

\section{Terpanes}

Kikinda crude oil: terpane distributions is typical for oils (Figure 7). They are characterized by predominance of thermodynamically more stable isomers with $17 \alpha(\mathrm{H}) 21 \beta(\mathrm{H})$ and $22(\mathrm{~S})$ configurations, by the presence of typical geoisomers. These compounds have never been reported in biosphere and recent singenetic organic matter. The oils contain of oleanane and gammacerane. Oleanane is an indicator of input from angiosperm land plantsand, gammacerane is an indicator of organic matter deposited under a stratified water column or from an evaporitic and hypersaline environment. Oleanane and $\% \mathrm{C}_{29}$ sterane can be indicatore of higher plant contribution (Table 7).

Velebit crud oil: terpane distributions is typical for oils (Figure 8), with characterization which was mentioned above. Values of terpane maturity ratios show that Velebit crude oil is less mature than Kikinda crude oil (Table 7). Because of biodegradation values of biomarker parameters could not be safely used, although steranes and terpanes are very resistant to biodegradation.

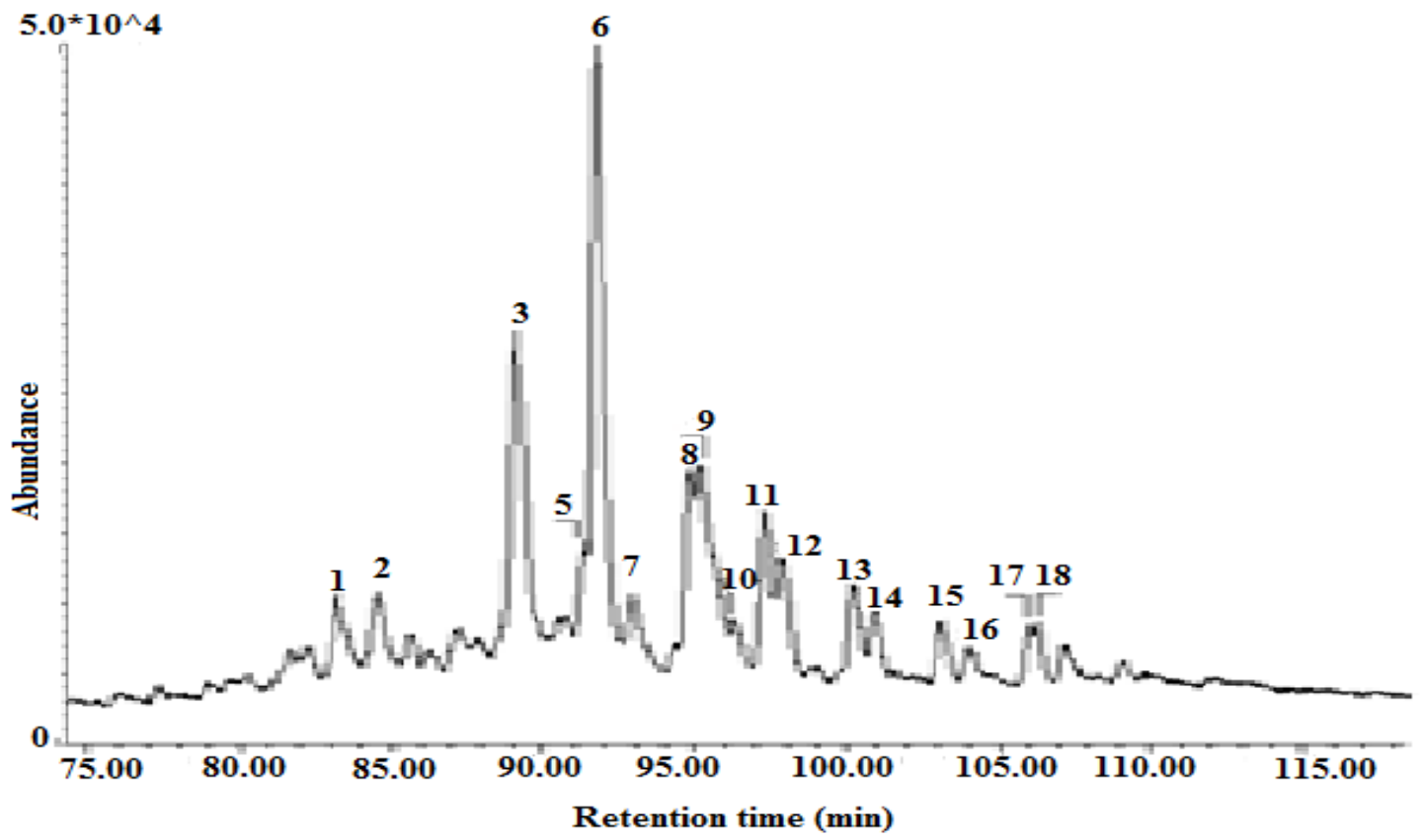

Figure 7: GC-MS chromatogram of terpanes m/z 191 of saturated fraction isolated from Kikinda crude oil (Peak identification is shown in Table 6). 


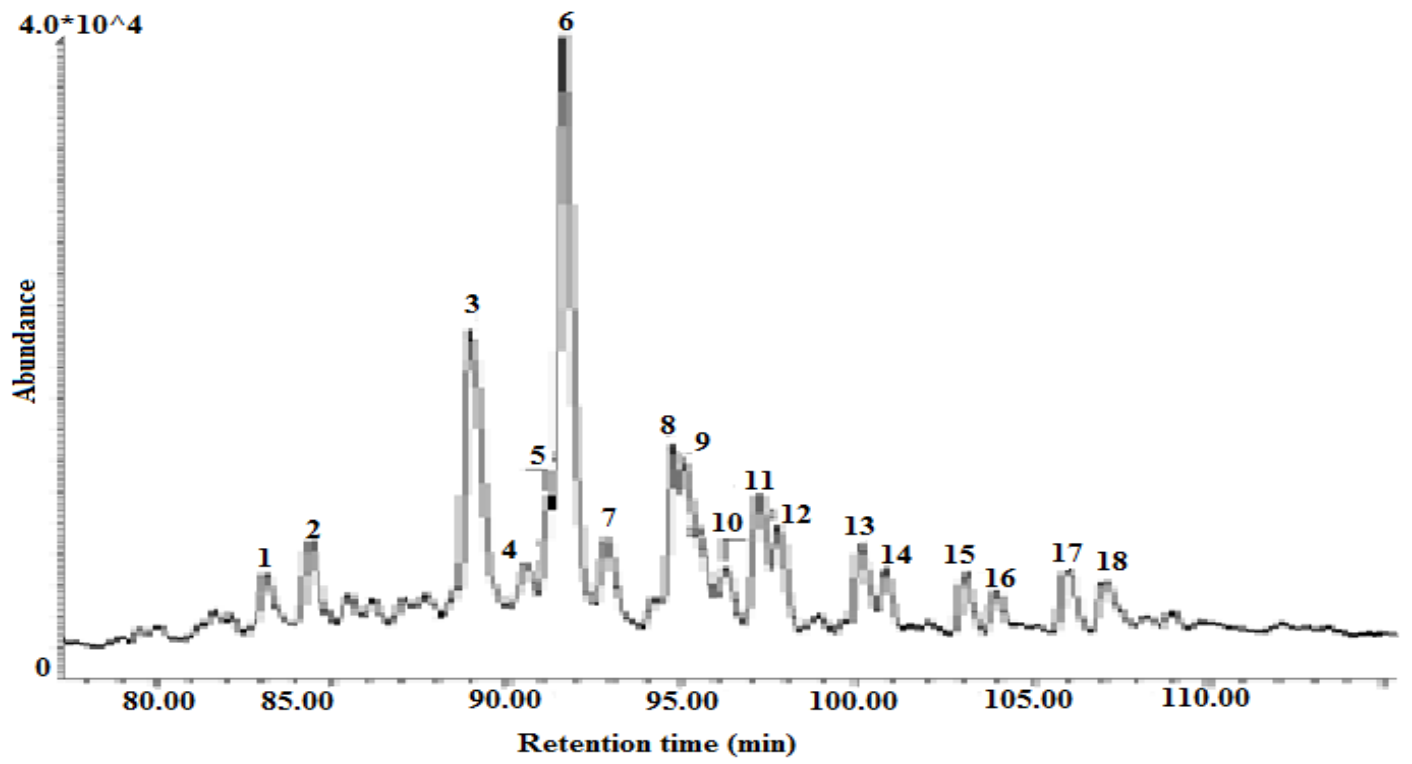

Figure 8: GC-MS chromatogram of terpanes $\mathrm{m} / \mathrm{z} 191$ of saturated fraction isolated from Velebit crude oil (Peak identification is shown in Table 6).

Table 6: Identification of the peaks in the chromatograms shown in Figures 7 and 8 (terpanes).

\begin{tabular}{|l|l|}
\hline Peaks & Compound \\
\hline 1 & $\mathrm{C}_{27} 18 \alpha(\mathrm{H}), 22,29,30$-trisnorhopane; $\mathrm{T}_{\mathrm{s}}$ \\
\hline 2 & $\mathrm{C}_{27} 17 \alpha(\mathrm{H}), 22,29,30$-trisnorhopane; $\mathrm{T}_{\mathrm{m}}$ \\
\hline 3 & $\mathrm{C}_{29} 17 \alpha(\mathrm{H}) 21 \beta(\mathrm{H})$-hopane; $\mathrm{C}_{29} \mathrm{H}$ \\
\hline 4 & $\mathrm{C}_{29} 17 \beta(\mathrm{H}) 21 \alpha(\mathrm{H})$-moretane; $\mathrm{C}_{29 \mathrm{M}}$ \\
\hline 5 & $\mathrm{Oleanan}$ \\
\hline 6 & $\mathrm{C}_{30} 17 \alpha(\mathrm{H}) 21 \beta(\mathrm{H})$-hopane; $\mathrm{C}_{30} \mathrm{H}$ \\
\hline 7 & $\mathrm{C}_{30} 17 \beta(\mathrm{H}) 21 \alpha(\mathrm{H})$-moretane; $\mathrm{C}_{30} \mathrm{M}$ \\
\hline 8 & $\mathrm{C}_{31} 17 \alpha(\mathrm{H}) 21 \beta(\mathrm{H}) 22(\mathrm{~S})$-hopane \\
\hline 9 & $\mathrm{C}_{31} 17 \alpha(\mathrm{H}) 21 \beta(\mathrm{H}) 22(\mathrm{R})$-hopane \\
\hline 10 & $\mathrm{Gamacerane}$ \\
\hline 11 & $\mathrm{C}_{32} 17 \alpha(\mathrm{H}) 21 \beta(\mathrm{H}) 22(\mathrm{~S})$-hopane \\
\hline 12 & $\mathrm{C}_{32} 17 \alpha(\mathrm{H}) 21 \beta(\mathrm{H}) 22(\mathrm{R})$-hopane \\
\hline 13 & $\mathrm{C}_{33} 17 \alpha(\mathrm{H}) 21 \beta(\mathrm{H}) 22(\mathrm{~S})$-hopane \\
\hline 14 & $\mathrm{C}_{33} 17 \alpha(\mathrm{H}) 21 \beta(\mathrm{H}) 22(\mathrm{R})$-hopane \\
\hline 15 & $\mathrm{C}_{34} 17 \alpha(\mathrm{H}) 21 \beta(\mathrm{H}) 22(\mathrm{~S})$-hopane \\
\hline 16 & $\mathrm{C}_{34} 17 \alpha(\mathrm{H}) 21 \beta(\mathrm{H}) 22(\mathrm{R})$-hopane \\
\hline 17 & $\mathrm{C}_{35} 17 \alpha(\mathrm{H}) 21 \beta(\mathrm{H}) 22(\mathrm{~S})$-hopane \\
\hline 18 & $\mathrm{C}_{35} 17 \alpha(\mathrm{H}) 21 \beta(\mathrm{H}) 22(\mathrm{R})$-hopane \\
\hline
\end{tabular}

Table 7: Values of specific organic geochemical parameters calculated from distributions and abundances of terpanes.

\begin{tabular}{|l|l|l|l|l|l|}
\hline Sample & $\begin{array}{l}\mathbf{C}_{\mathbf{3 1}} \text { hopane- } \\
\mathbf{2 2} / \mathbf{( 2 2 S + 2 2})\end{array}$ & $\begin{array}{l}\mathbf{C}_{\mathbf{3 0}} \text { moretan/ } \\
\mathbf{C}_{\mathbf{3 0}} \text { hopane }\end{array}$ & $\mathbf{T s} / \mathbf{T m}$ & $\begin{array}{l}\text { Oleana/ } \\
\mathbf{C}_{\mathbf{3 0}} \text { hopane }\end{array}$ & $\begin{array}{l}\text { Gamaceran/ } \\
\text { C 30hopane }\end{array}$ \\
\hline Kikinda & 0.51 & 0.09 & 1.07 & 0.03 & 0.05 \\
\hline Velebit & 0.55 & 0.13 & 0.65 & 0.067 & 0.075 \\
\hline
\end{tabular}




\section{Conclusion}

In this study two crude oil samples were investigated to present the difference between biodegraded (Velebit) and non-degraded (Kikinda) oil. Two samples are from the Velebit oil-gas field and the Kikinda oil-gas field. These are two of the largest oil and gas deposits in the Serbian part of the Pannonian Basin. In the experimental part of this work, two samples of crude oil were separated by column chromatography. Saturated hydrocarbons were analyzed by gas chromatography-mass spectrometry instruments.

The values of group organic geochemical parameters indicate that soluble organic matter in both samples of crude oil is mainly represented by hydrocarbons, which is in accordance to the high maturity of the crude oil, as highly mature organic matter.

Based on the abundance and distribution of biomarkers, it could be conclude that the distribution is typical of oil in both samples, with difference in the distribution of n-alkane. GC-MS chromatogram of n-alkanes and isoprenoids of saturated fraction isolated from Velebit crude oil show the distribution typical of oils altered by biodegradation. The n-alkanes are not the most abundant, while pristane (Pr) and phytane (Phy) dominate. In the distribution of steranes and terpanes, biodegradation was not observed, probably because steranes and terpanes are more resistant to biodegradation. Values of maturity ratios show that Velebit crude oil is less mature than Kikinda crude oil.

\section{References}

[1] Beškoski V., Gojgić-Cvijović G., Jovančićević B., Vrvić M., in Gas Chromatography Biochemicals, Narcotics and Essential Oils, B. Salih, Ö. Çelikbıçak, Eds., InTech, Rijeka, Croatia, 2012

[2] Dougle W. Waples, 1945-Geochemistry in petroleum exploration.

[3] Niessen W.M.A. (2001) Current practise of Gas chromatography-Mass spectrometry; Copyright by Marcel Dekker, Inc.

[4] Nytoft H.P., G. Kildahl-Andersen, O.J. Samuel, Org. Geochem. 41 (2010) 1104

[5] Peters, K.E., 1986. Guidelines for evaluating petroleum source rock using programmed pyrolysis. American Association of Petroleum Geologists Bulletin 70, 318-329.

[6] Peters, K.E., Walters, C.C., Moldowan, J.M., 2005. The Biomarker Guide, Volume 2: Biomarkers and Isotopes in the Petroleum Exploration and Earth History. Cambridge University Press, Cambridge, UK.

[7] Peters, K.E., Moldowan, J.M., Schoell, M., Hempkins, W.B., 1986. Petroleum isotopic and biomarker composition related to source rock organic matter and depositional environment. Organic Geochemistry 10, 17-27.

[8] Peters, K.E., Moldowan, J.M., 1991. Effects of source, thermal maturity and biodegradation on the distribution and isomerization of homohopanes in petroleum. Organic Geochemistry 17

[9] Peters, K.E., Moldowan, J.M., 1993. The biomarker guide. Interpreting molecular fossils in petroleum and ancient sediments. Prentice Hall, Englewood Cliffs.

[10] Philp, R.P., 1985. Fossil fuel biomarkers. Applications and spectra. Elsevier, Amsterdam.

[11] Philp R.P., T.D. Gilbert and J. Friedrich (1981) Bicyclic sesquiterpenoids and diterpenoids in Australian crude oils; Geochimica et Cosmochimica Acta, 45, 1173-80.

[12] R.P. Philp, B.R.T. Simoneit and T.D. Gilbert, (1983) Diterpenoids in crude oils and coals of South Eastern Australia; 698-704. 
[13] Rubinstein, I., Sieskind, O., Albrecht, P., 1975. Rearranged steranes in a shale: Occurrence and simulated formations. Journal of the Chemical Society, Perkin Transaction 1, 1833-1836.

[14] Šolević, T., Stojanović, K., Bojesen-Koefoed, J., Nytoft, H.P., Jovančićević, B., Vitorović, D., 2008. Origin of oils in the Velebit oil-gas field, SE Pannonian Basin, Serbia - Source rocks characterization based on biological marker distributions. Organic Geochemistry 39, 118-134.

[15] Stojanović, K., Jovančićević, B., Šajnović, A., Sabo, T., Vitorović, D., Schwarzbauer, J., Golovko, A. 2009. Pyrolysis and Pt(IV)- and Ru(III)-ion catalyzed pyrolysis of asphaltenes in organic geochemical investigation of a biodegraded crude oil (Gaj, Serbia). Fuel 88, 287-296.

[16] Štrbac S., Gajica G., Šajnović A., Vasić N., Stojanović K., Jovančićević B. The use of biological markers in determination of origin and type of organic matter in the Tisza river sediments. Journal of the Serbian Chemical Society, 2013

[17] Tissot, B.P., Welte, D.H., 1984. Petroleum Formation and Occurrence, 2nd Ed. Springer-Verlag, Heidelberg, Germany, 1984

[18] Višekruna, Č., 1988. Vazduhoplovni pogonski materijali. I deo, Goriva. Vojnoizdavački novinski centar, Beograd

[19] Vitorović, D., Jovančićević, B., 2005. Osnovi organske geohemije, Hemijski fakultet Univerziteta u Beogradu, Beograd.

[20] Volkman, J.K., Alexander, R., Kagi, R.I., Woodhouse, G.W., 1983. Demethylated hopanes in crude oils and their applications in petroleum geochemistry. Geochim Comochim Acta 47

[21] Volkman, J.K., 2003. Sterols in microorganisms. Applied Microbiology and Biotechnology 60, 496-506.

[22] Welte, D.H., 1989. The changing face of geology and future needs. Geologische Rundschau (International Journal of Earth Sciences) 78, 7-20.

*Corresponding author.

E-mail address: hamzakhlifa2009@gmail.com 